\title{
RECONSTRUCTION OF PREHISTORIC AND MEDIEVAL DIETARY PATTERNS IN THE RUSSIAN FAR EAST: A REVIEW OF CURRENT DATA
}

\author{
Yaroslav V Kuzmin \\ Institute of Geology \& Mineralogy, Siberian Branch of the Russian Academy of Sciences, Novosibirsk 630090, Russia; also \\ Tomsk State University, Tomsk 634050, Russia. Email: kuzmin@fulbrightmail.org.
}

\begin{abstract}
An overview of current knowledge on the human paleodiet of the southern Russian Far East is presented. The earliest data are available for the Neolithic complexes of Primorye Province, dated to 7000-5800 BP. For 10 humans from the coastal site of Boisman 2, a heavy reliance on marine fish and mammals ( $70-80 \%$ of the total diet) has been established; this is similar to the Jomon and Chulmun complexes of Hokkaido Island and Korea. For two individuals from the inland site of Chertovy Vorota, a mixture of terrestrial and riverine (including anadromous species such as salmon, $\sim 25 \%$ of the total diet) food resources is evident. In the Amur River basin, the diet of the Paleometal (i.e. Bronze/Early Iron Ages) population (dated to $\sim 2500-1800 \mathrm{BP}$ ) was probably based on a mixture of $\mathrm{C}_{4}$ plants (millet, $\sim 50-60 \%$ of the total diet), $\mathrm{C}_{3}$ plants, and terrestrial animals, while in the Middle Ages ( 1500-300 BP) the contribution of $\mathrm{C}_{4}$ food was lower at $\sim 20-25 \%$. On Sakhalin Island, the maritime-oriented economy existed for a long time, at least since the Late Neolithic/Paleometal Age (dated to $\sim 2500-1800 \mathrm{BP}$ ) and until the ethnographic time period (from the 17 th-18th centuries $\mathrm{AD}$ onwards). Up to $\sim 80-90 \%$ of the diet consisted of marine mammals and fish, and this is in accord with dietary patterns of the Epi-Jomon and Okhotsk cultural complexes on Hokkaido Island. Information on the paleodiet of the coastal populations of the Japan and Okhotsk Seas should be taken into account when calibration of ${ }^{14} \mathrm{C}$ dates run on human bones from these regions is undertaken, because the predominant consumption of marine food caused a distortion of the true ${ }^{14} \mathrm{C}$ age.
\end{abstract}

\section{INTRODUCTION}

Studies of prehistoric diet allow us to establish securely the main sources of subsistence, primarily for the protein part of the nutrition. In the Russian Far East, the first research on stable isotopes in human bone collagen for this purpose was done in the late 1980s (Roksandic et al. 1988), and more work was conducted in the 1990s-2000s (Kuzmin et al. 2002, 2003, 2007a,b; Zhang et al. 2009). However, the amount of information on paleodiet in this vast region covering Primorye [Maritime] Province, the Amur River basin, and Sakhalin Island (Figure 1) is still insufficient for a detailed reconstruction of ancient diets. The dearth of human remains and their poor preservation due to acidic soils hamper in-depth studies of prehistoric subsistence. Nevertheless, some general patterns of the prehistoric diet for this region can be determined, and this is the aim of the current review.

The necessity of stable isotope research on human bone collagen from prehistoric complexes in the Russian Far East can be justified by ongoing debates about the timing for the beginning of maritime adaptation (e.g. Popov and Yesner 2006; Kuzmin 2009) and agriculture (e.g. Kuzmin 2013). As is well known, solely archaeological data on these subjects are often not very convincing and precise, and the application of scientific methods is therefore needed. Also, the construction of a reliable chronological framework for the Neolithic-Paleometal cultural complexes requires a knowledge of the human diet in order to introduce necessary amendments to the ${ }^{14} \mathrm{C}$ dates in cases where reservoir age corrections need to be applied.

Although some aspects of paleodietary studies in the Russian Far East have been discussed previously (see Kuzmin et al. 2002, 2003, 2007b), here, the first systematic overview of the published data is presented and compared with information about the carbon and nitrogen stable isotope composition of bone collagen from the neighboring populations of Northeast Asia (north and northeast China, Japanese Islands, and Korean Peninsula), which was not available until the mid-2000s. Data on the prehistoric subsistence and chronology of the Russian Far East, obtained by the author over the last 30 years, are summarized in Kuzmin $(2006,2009$, 2012, 2013) and Kuzmin and Rakov (2011), and are used in this overview.

Proceedings of Radiocarbon and Diet: Aquatic Food Resources and Reservoir Effects First International Conference, 24-26 September 2014, Kiel, Germany

Edited by Ricardo Fernandes, John Meadows, and Alexander Dreves 


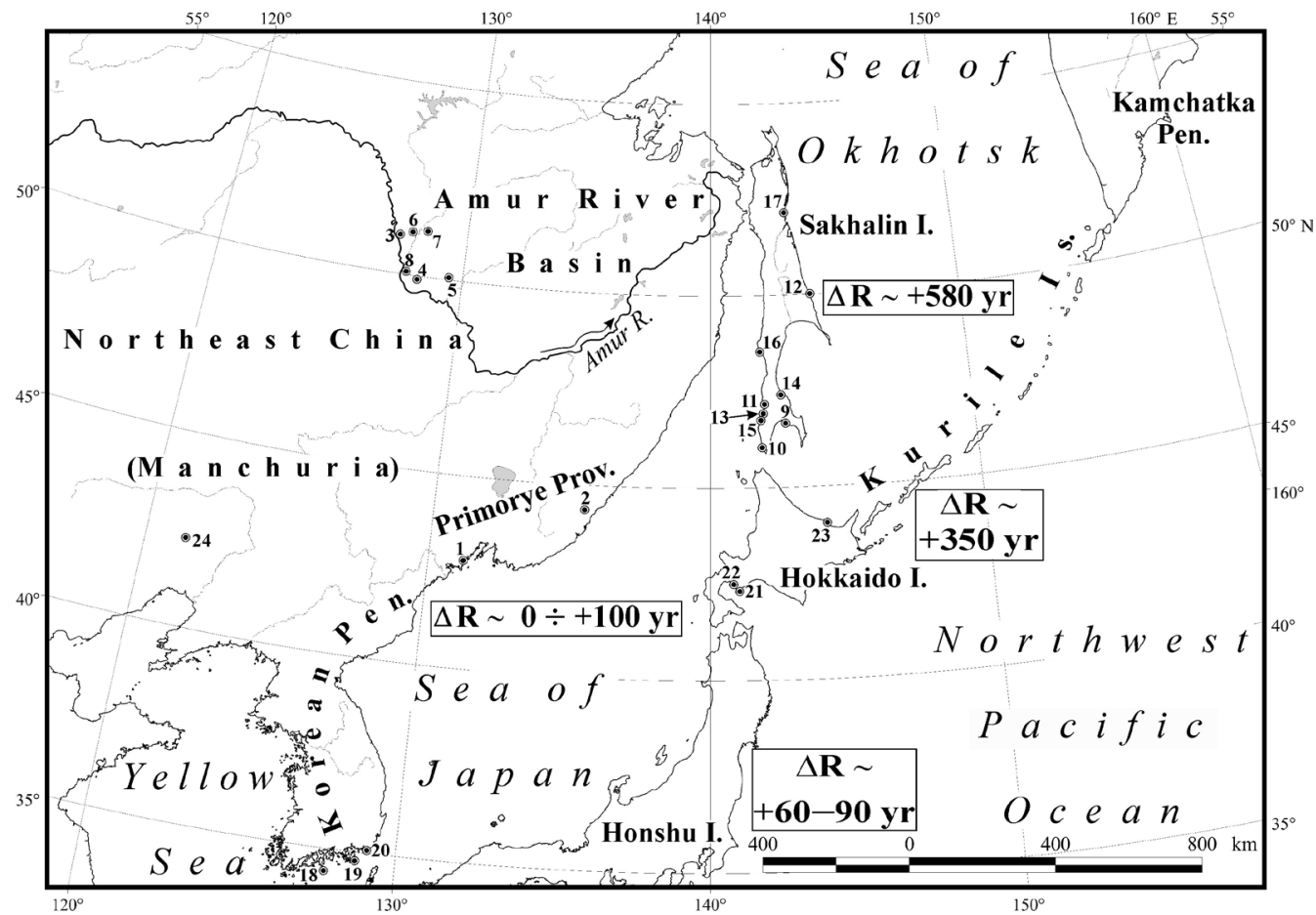

Figure 1 Location of the studied sites in the Russian Far East and relevant sites in Northeast Asia, and $\Delta \mathrm{R}$ values for this region. Far Eastern Russian sites: (1) Boisman 2; (2) Chertovy Vorota; (3) Alekseevsky Bugor; (4) Osinovoe Ozero; (5) Troitsky Cemetery; (6) Pryadchino; (7) Bolshaya Sazanka; (8) Kanukurgan; (9) Susuya; (10) Kuznetsovo 1; (11) Antonovo; (12) Bogataya 1; (13) Kalinino 1 and 1A; (14) Pasechnaya 2; (15) Asanai 1; (16) Staroainskoe 1; (17) Kaurunari. Other sites and regions: (18) Ando; (19) Daepo; (20) Tongsamdong; (21) Kitakogane; (22) Usu-moshiri; (23) Moyoro; (24) Chifeng.

Information acquired in the last 3-4 decades on stable isotope values from human bone collagen in Northeast Asia (e.g. Minagawa and Akazawa 1992; Yoneda et al. 2002, 2004; Pechenkina et al. 2005; Choy and Richards 2010; Kusaka et al. 2010; Naito et al. 2010; Lanehart et al. 2011; Tsutaya et al. 2014) was used in this overview as a background. People who consumed terrestrial proteins (from herbivores and $\mathrm{C}_{3}$ plants) usually have $\delta^{13} \mathrm{C}$ values around $-20 \%$, and those who subsided mainly on marine protein (from mammals, fish, and mollusks) have $\delta^{13} \mathrm{C}$ values around $-12 \%$ (e.g. Choy and Richards 2010). In the absence of marine influence, human bone collagen $\delta^{13} \mathrm{C}$ values $\leq-18 \%$ indicate subsistence on mainly $\mathrm{C}_{3}$ foodchains; $\delta^{13} \mathrm{C}=-18 \%$ to $-12 \%$, a mixture of $\mathrm{C}_{3}$ and $\mathrm{C}_{4}$ foods; and $\delta^{13} \mathrm{C}=>-12 \%$, point to a highly $\mathrm{C}_{4}$-dependent diet (e.g. Ma et al. 2014; see Figure 2).

\section{MATERIALS AND METHODS}

For this review, I used the results of $\mathrm{C}$ and $\mathrm{N}$ isotope analysis of 36 samples of human bone from 18 prehistoric and Medieval sites in the Russian Far East, belonging to adult individuals and published previously (see Figure 1 and Table 1). Table 1 summarizes the existing data. The extraction of collagen and measurements of $\delta^{13} \mathrm{C}$ and $\delta^{15} \mathrm{~N}$ values follow a standard protocol (e.g. Richards and Hedges 1999; Choy and Richards 2010). It was performed at the National Institute for Environmental Studies (NIES; Tsukuba, Japan) and the Research Laboratory for Archaeology and the History of Art, Oxford University (ORAU; Oxford, UK). Details of the procedures are described in the relevant publications (e.g. Kuzmin et al. 2002). The $\mathrm{C} / \mathrm{N}$ atomic ratios for almost all samples (besides the Susuya site where it was not determined; see Table 1) are within the accepted range of 2.9-3.6 (DeNiro 1985); the results obtained are therefore considered to be reliable. 
Table 1 Summary of existing data on carbon and nitrogen stable isotope values for collagen from prehistoric human remains in the Russian Far East (after Roksandic et al. 1988; Kuzmin et al. 2002, 2003, 2007b; Zhang et al. 2009).

\begin{tabular}{|c|c|c|c|c|c|}
\hline Region, site, individual & $\mathrm{Age}^{\mathrm{a}}$ & $\begin{array}{l}\delta^{13} \mathrm{C} \\
(\%)\end{array}$ & $\begin{array}{l}\delta^{15} \mathrm{~N} \\
(\% 0)\end{array}$ & $\begin{array}{l}\mathrm{C} / \mathrm{N} \\
\text { ratio }\end{array}$ & Reference $^{\mathrm{b}}$ \\
\hline \multicolumn{6}{|l|}{ Primorye [Maritime] Province } \\
\hline Boisman 2 & $\mathrm{~N}$ & $-14.3 \pm 0.4^{c}$ & $+18.1 \pm 0.5^{\mathrm{c}}$ & $3.23^{\mathrm{c}}$ & [1] \\
\hline Chertovy Vorota & $\mathrm{N}$ & -17.4 & +12.9 & 3.16 & [1] \\
\hline Chertovy Vorota & $\mathrm{N}$ & -17.7 & +12.2 & 3.18 & [1] \\
\hline \multicolumn{6}{|l|}{ Amur River basin } \\
\hline Alekseevsky Bugor & $\mathrm{PM}$ & -12.4 & +9.7 & 3.29 & {$[2]$} \\
\hline Osinovoe Ozero & EMA & -15.1 & +9.9 & 3.19 & {$[2]$} \\
\hline Troitsky Cemetery (skeleton M232) & EMA & -14.1 & +9.5 & 2.96 & [3] \\
\hline Troitsky Cemetery (skeleton M250) & EMA & -14.9 & +8.9 & 2.99 & {$[3]$} \\
\hline Troitsky Cemetery (skeleton M254) & EMA & -13.9 & +11.0 & 2.97 & [3] \\
\hline Troitsky Cemetery (skeleton M255) & EMA & -14.8 & +10.3 & 2.97 & {$[3]$} \\
\hline Pryadchino (skeleton 1) & LMA & -18.5 & +8.3 & 3.25 & [2] \\
\hline Pryadchino (skeleton 2) & LMA & -18.3 & +9.1 & 3.25 & [2] \\
\hline Pryadchino (skeleton 3) & LMA & -17.9 & +9.1 & 3.23 & [2] \\
\hline Bolshaya Sazanka & LMA & -18.3 & +9.1 & 3.25 & {$[2]$} \\
\hline Kanukurgan & LMA & -15.5 & +9.4 & 3.34 & {$[2]$} \\
\hline \multicolumn{6}{|l|}{ Sakhalin Island } \\
\hline Susuya & $\mathrm{PM}$ & -14.1 & n.a. ${ }^{d}$ & n.a. & {$[4]$} \\
\hline Susuya & $\mathrm{PM}$ & -15.7 & n.a. & n.a. & {$[4]$} \\
\hline Kuznetsovo 1 (burial 2) & A & -14.9 & +17.2 & 3.38 & [5] \\
\hline Kuznetsovo 1 (burial 5) & A & -14.5 & +18.1 & 3.29 & [5] \\
\hline Kuznetsovo 1 (burial 6) & $\mathrm{A}$ & -14.1 & +18.3 & 3.23 & {$[5]$} \\
\hline Antonovo & A & -15.2 & +17.4 & 3.32 & [5] \\
\hline Bogataya 1 & A & -15.0 & +17.9 & 3.31 & [5] \\
\hline Kalinino 1 & $\mathrm{~A}$ & -16.8 & +16.8 & 3.35 & {$[5]$} \\
\hline Kalinino 1A & $\mathrm{A}$ & -14.6 & +19.0 & 3.25 & {$[5]$} \\
\hline Pasechnaya 2 & $\mathrm{~A}$ & -14.9 & +18.8 & 3.37 & [5] \\
\hline Asanai 1 & $\mathrm{~A}$ & -14.3 & +18.5 & 3.35 & {$[5]$} \\
\hline Staroainskoe 1 & A & -17.6 & +19.0 & 3.20 & [5] \\
\hline Kaurunari & $\mathrm{N}(?)$ & -14.4 & +18.3 & 3.20 & [5] \\
\hline
\end{tabular}

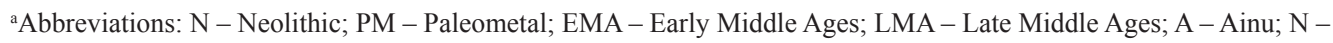
Nivkh.

b[1] - Kuzmin et al. (2002); [2] - Kuzmin et al. (2003); [3] - Zhang et al. (2009); [4] - Roksandic et al. (1988); [5] Kuzmin et al. (2007b). All $\delta^{13} \mathrm{C}$ and $\delta^{15} \mathrm{~N}$ values from [1-5] are rounded to the next $0.1 \%$.

${ }^{\mathrm{c} A v e r a g e}$ of 10 samples (see Kuzmin et al. 2002). The $\mathrm{C} / \mathrm{N}$ atomic ratios are in the 3.16-3.28 range.

${ }^{\mathrm{d}}$ Not available.

No relevant data on stable isotope composition for animals are available for the Russian Far East. As such, stable isotope values for collagen of terrestrial and marine mammals, mollusks, fish, and plants (see Figure 2) from the study on the Chulmun (Neolithic) human diet of Korea (Choy and Richards 2010) have been used as isotopic baseline for the Russian Far East. It seems appropriate to use information from the neighboring part of Northeast Asia, considering the similar climate, vegetation, and fauna of Korea and the Russian Far East. 


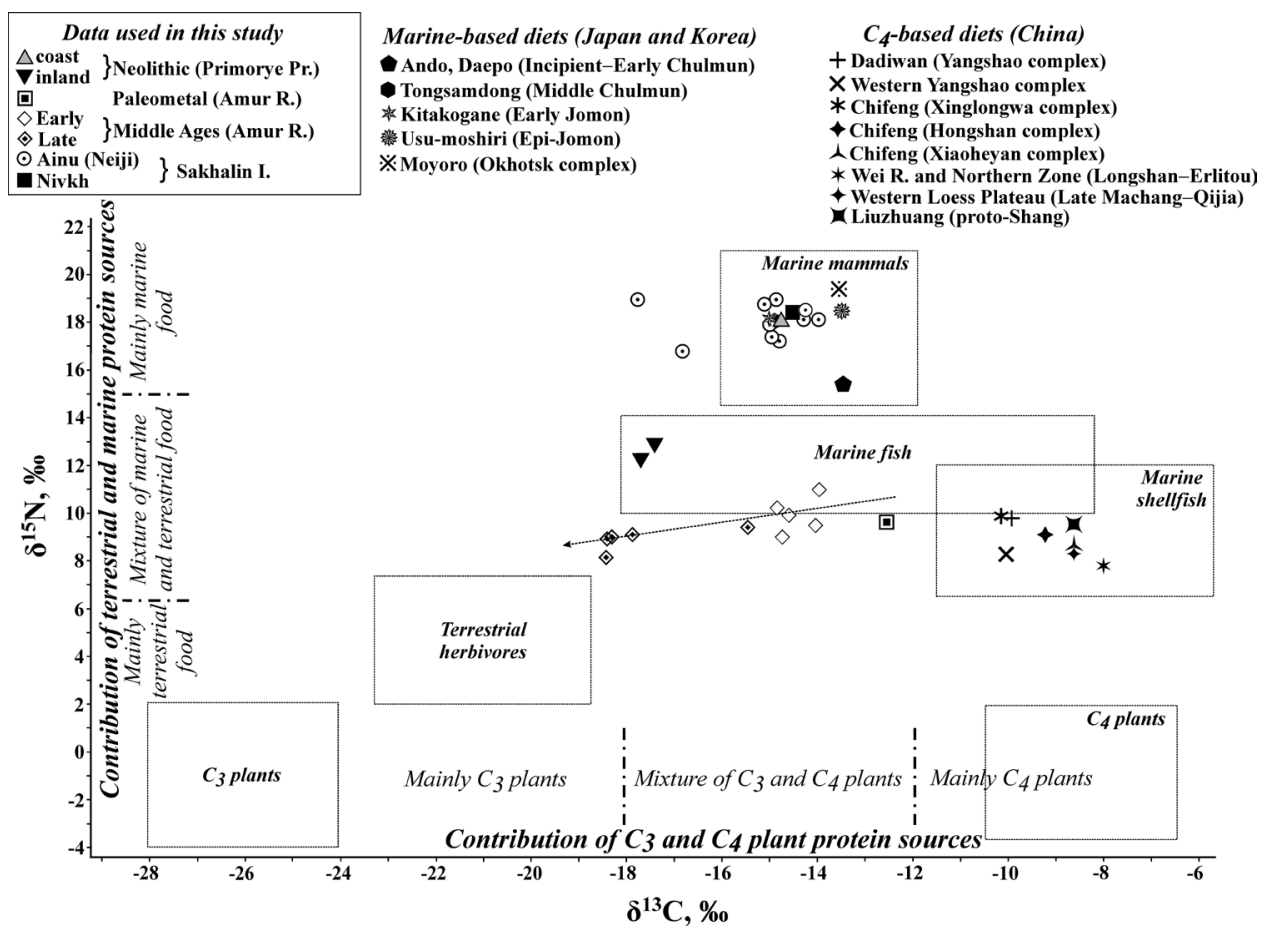

Figure 2 Summary of the $\mathrm{C}$ and $\mathrm{N}$ isotope values for the prehistoric and Medieval populations of the Russian Far East (Kuzmin et al. 2002, 2003, 2007a,b) and neighboring regions of Northeast Asia (see references in the text); boxes with ranges of the main dietary sources are from Choy and Richards (2010). A dashed line with arrow shows the trend in $\mathrm{C}_{4}$ plant consumption for the Amur River basin (see text).

For comparison of the Russian Far Eastern data with the other parts of Northeast Asia where paleodietary studies are more advanced, the latest summaries on the diet of maritime-oriented prehistoric populations of Japan and Korea have been used (Naito et al. 2010; Choy et al. 2012; Tsutaya et al. 2013 , 2014). The latter demonstrates a significant contribution of high trophic level protein from marine organisms to human diet in Neolithic (Jomon) and post-Neolithic (Epi-Jomon) times (e.g. Kusaka et al. 2010; Naito et al. 2010; Tsutaya et al. 2014; see Figure 2). For the isotopic reference on the prehistoric diet with millet consumption, the latest sources available for northern and northeastern China have been used (Barton et al. 2009; Liu et al. 2012; Hou et al. 2013; Atahan et al. 2014; Ma et al. 2014).

A general description of prehistoric cultural complexes from the Russian Far East and their paleoeconomy can be found in recent summaries (Popov et al. 2014; Tabarev 2014; see also Kuzmin 1997, 2006). The archaeology of the Neolithic complexes in Primorye is presented by Zhushchikhovskaya (2006). Overall, hunting-fishing-gathering communities existed in the Russian Far East throughout the Paleolithic and the major part of the Neolithic; at the end of the latter period, the first traces of millet cultivation are known from both archaeological (e.g. Andreeva 2005) and archaeobotanical (e.g. Kuzmin 2013) sources. Plant cultivation and animal husbandry developed slowly in the Paleometal period (combined Bronze and Early Iron Ages) following the Neolithic (e.g. Kuzmin and Rakov 2011), and they finally became the dominant types of the economy in the Middle Ages (e.g. Andreeva 2005). In the following, some essential details are provided.

The Neolithic sites of Boisman 2 and Chertovy Vorota are located in Primorye Province (Figure 1). 
The Boisman 2 site is situated on the coast of Peter the Great Gulf, and represents a shell midden with abundant remains of both marine (mammals, mollusks, and fish) and terrestrial (mammals) fauna (Kuzmin et al. 2002; Kuzmin 2006, 2009; Popov and Yesner 2006). The population of the Boisman 2 site subsisted on hunting marine and terrestrial mammals, and marine fish and mollusks (based on zooarchaeological data; see Popov and Yesner 2006), and possibly the gathering of wild plants (e.g. Kuzmin 1997, 2006). The site is ${ }^{14} \mathrm{C}$ dated to $\sim 6700-5500$ BP (charcoal) (Kuzmin 2012). The Chertovy Vorota site is located in a limestone cave $\sim 30 \mathrm{~km}$ from the seashore; it is abundant in remains of terrestrial mammals, birds, and some anadromous fish (salmon) (e.g. Kuzmin 2009). The subsistence of the people was based mainly on hunting terrestrial mammals according to the zooarchaeological evidence (e.g. Kuzmin 1997, 2006). The site is ${ }^{14} \mathrm{C}$ dated to $\sim 8200-5900 \mathrm{BP}$ according to charcoal and animal bone dates (Kuzmin et al. 2012).

In the Amur River basin, human bones from two prehistoric complexes, Paleometal and Medieval, were studied (Figure 1). The Aleskeevsky Bugor site is dated to 2500-1800 BP (charcoal). Two sites, Osinovoe Ozero and Troitsky Cemetery, belong to the Early Medieval Mohe cultural complex and are dated to $\sim 1500-1000$ BP (charcoal). Other sites (Pryadchino, Bolshaya Sazanka, and Kanukurgan) belong to the Vladimirovka complex of the Late Middle Ages, dated to $~ 800-300$ BP (charcoal). It has been suggested that the economy of the Paleometal and Medieval cultural complexes in the Amur River basin was based on cereal cultivation (millet, wheat, and barley), animal breeding, and hunting and fishing, although zooarchaeological and archaeobotanical data for this region are very scant (e.g. Kuzmin 2006; Kuzmin and Rakov 2011).

For Sakhalin Island, human bones from several coastal sites were analyzed (Figure 1). The Kaurunari site may correspond to the early Nivkh (one of the native people on Sakhalin) settlements probably dated to the 17 th-18th centuries AD. The remaining sites belong to the Ainu (Neiji) cultural complex, widely distributed in the southern and central parts of the island in the late Medieval period, and dated to $\sim 800-400$ BP (charcoal) (Kuzmin et al. 2004). The Ainu economy was primarily based on hunting marine and terrestrial mammals, marine fishing, and gathering based on zooarchaeological, archaeobotanical, and ethnographic data (e.g. Crawford and Takamiya 1990; D’Andrea et al. 1995; Fitzhugh and Dubreuil 1999).

\section{RESULTS AND DISCUSSION \\ Primorye Province}

Human bones from two Neolithic sites, Boisman 2 (10 samples) and Chertovy Vorota (two samples) were studied for $\mathrm{C}$ and $\mathrm{N}$ stable isotopes. High $\delta^{15} \mathrm{~N}$ values (average $+18.1 \pm 0.5 \%$ ) and elevated $\delta^{13} \mathrm{C}$ values (average $-14.3 \pm 0.4 \%$ ) suggest that the inhabitants of Boisman 2 had a clear reliance on marine food consumption, similar to the Jomon populations of Hokkaido Island (e.g. Minagawa and Akazawa 1992; Yoneda et al. 2002) and the people of the Chulmun complex in the southern Korean Peninsula (Choy et al. 2012) (see Figure 2). This is consistent with the results of the quantitative evaluation of the high trophic level food share (e.g. seals) from the Jomon of Hokkaido (Yoneda et al. 2002; Naito et al. 2010). It is reasonable to assume that marine mammals (mainly harbor seals and Steller sea lions; see Popov and Yesner 2006) contributed greatly to the diet of the Boisman 2 population, comprising up to $\sim 70-80 \%$ of the total diet, similar to the data from Hokkaido (e.g. Naito et al. 2010). It is noteworthy that Boisman 2 is the earliest cultural complex in the Russian Far East, which demonstrates the full-scale maritime adaptive features of the population, like seal hunting and shellfish collecting (e.g. Popov and Yesner 2006:475; Kuzmin 2009, 2012:729-30).

As for the inland Chertovy Vorota site, some of its inhabitants at 7000-6900 BP (based on direct

${ }^{14} \mathrm{C}$ dating of human bones; see Kuzmin et al. 2002) relied mainly on terrestrial sources (mammals, 
rodents, and birds; see Kuzmin 1997:174). The slightly elevated $\delta^{15} \mathrm{~N}$ value (+12.2 to $-12.9 \%$ ) (see Table 1; Figure 2) suggests some aquatic protein contribution, most probably from anadromous fish. This may indicate the consumption of salmon, which runs upstream from the Sea of Japan; its share can be estimated as $\sim 25 \%$ of the total diet based on a simple linear model (Kuzmin et al. 2002). This is similar to the diet of the Jomon populations of Honshu Island away from the coast with consumption of salmon based on stable isotope data (e.g. Minagawa and Akazawa 1992; Yoneda et al. 2004). Chertovy Vorota is the earliest site that provides solid evidence of anadromous fish procurement in the southern Russian Far East corresponding to the Early Neolithic, 7000 BP.

\section{Amur River Basin}

In the landlocked part of the Amur River basin between the Zeya and Bureya Rivers, human bones from Early Iron Age and Medieval sites have been analyzed. In total, 11 specimens from six sites have been examined (see Figure 1 and Table 1). Although the sample is relatively small, some conclusions can be drawn. The Early Iron Age individual from the Alekseevsky Bugor site apparently had a mixed diet of plant and animal foods, with a large proportion of $\mathrm{C}_{4}$ plants (millet) comprising more than $50 \%$ of the total diet (based on a simple linear model). In the following Medieval period, the amount of $\mathrm{C}_{4}$ plants in the diet of the Amur River basin population dropped significantly, down to $\sim 20-25 \%$ of total consumption (Figure 2). The $\delta^{13} \mathrm{C}$ values for five individuals of the Mohe complex of the Early Middle Ages (average $-14.6 \pm 0.53 \%$ ) are higher than those for five individuals from the Vladimirovka complex of the Late Middle Ages (average $-17.7 \pm 1.3 \%$ ). This might reflect a more intensive consumption of $\mathrm{C}_{4}$ plants in the earlier Medieval times (Mohe) than in the later time (Vladimirovka) because the average $\delta^{15} \mathrm{~N}$ values are similar ( $+9.9 \pm 0.8 \%$ vs. $+9.0 \pm 0.4 \%$ o). Therefore, the difference cannot be explained by a greater consumption of aquatic food by the earlier populations.

It is clear that in the Paleometal and Middle Ages of the Amur River basin, the consumption of millet was never high compared to the Neolithic (Yangshao, Xinglongwa, Hongshan, and Machang complexes; see Pechenkina et al. 2005; Barton et al. 2009; Lanehart et al. 2011; Liu et al. 2012; Atahan et al. 2014; Ma et al. 2014) and Bronze Age (Xiaoheyan, Erlitou, Qijia, and proto-Shang complexes; see Liu et al. 2012; Hou et al. 2013; Atahan et al. 2014; Ma et al. 2014) in the northern and northeastern parts of China (Figure 2). Millet was apparently the first cultigen in the Russian Far East according to archaeobotanical data (see review in Kuzmin 2013). Unfortunately, no Late Neolithic-Bronze Age human bone samples from the entire region dated to the initial agricultural time, $\sim 5000-2500 \mathrm{BP}$, have been found and analyzed in order to detect the presence of $\mathrm{C}_{4}$ plant isotopic signature.

\section{Sakhalin Island}

Little information is available on the diet of the Late Neolithic/Paleometal inhabitants of Sakhalin Island (Roksandic et al. 1988). For two skeletons at the Susuya [Susuia] site, with an age of $\sim 2500$ $1850 \mathrm{BP}$ based on associated charcoal ${ }^{14} \mathrm{C}$ dates (Kuzmin et al. 2004), the $\delta^{13} \mathrm{C}$ values $(-14.1 \%$ and $-15.7 \%$; see Table 1) suggest significant amounts of marine protein. More data are available on the human diet of the Ainu complex of the late Medieval period (Table 1; Figure 2). The average values of 10 samples are $\delta^{13} \mathrm{C}=-15.2 \pm 1.1 \%$ and $\delta^{15} \mathrm{~N}=+18.1 \pm 0.8 \%$. It is clear that the ancient Ainu people obtained most of their dietary protein from marine sources (see Choy and Richards 2010:6). This conclusion is based on the similarity with $\delta^{13} \mathrm{C}$ and $\delta^{15} \mathrm{~N}$ isotopic data for populations of the Epi-Jomon and Okhotsk cultural complexes of neighboring Hokkaido Island where the proportion of marine food in the human diet was estimated as $\sim 80-90 \%$ (Tsutaya et al. 2013, 2014). The single Nivkh (?) sample (Kaurunari site) is isotopically similar to those of the Ainu culture (Figure 2). 


\section{MAIN FEATURES OF THE NEOLITHIC-MEDIEVAL DIETS IN THE RUSSIAN FAR EAST}

In the coastal part of the mainland Russian Far East, particularly in Primorye Province, the active exploitation of marine resources (mammals, fish, and mollusks) can now be securely established since the Early-Middle Neolithic, 5800-5400 BP, based on stable isotope data for human bone collagen. This conclusion would not otherwise be possible based on the zooarchaeological data because the major source of protein is not evident. This is due to an almost equal amount of bones belonging to both terrestrial and marine mammals in the shell midden (e.g. Popov and Yesner 2006).

The procurement of anadromous fish (salmon) along the rivers of Primorye, which flow to the Sea of Japan, can be detected even earlier, at $\sim 000$ BP, corresponding to the Early Neolithic, using direct data carbon and nitrogen stable isotopes in human bones. The claims of earlier salmon fishing in the final Upper Paleolithic of Primorye Province, dated to $\sim 15,000-11,000$ BP, are based solely on archaeological and ethnographical data (see discussion in Kuzmin 2009), and require more substantial justification. To date, salmon fishing at $\sim 10,900-10,400 \mathrm{BP}$ has only been documented for the northern Russian Far East, namely Kamchatka Peninsula (e.g. Kuzmin 2009).

In the inland part of the Russian Far East, one can assume that the major part of the human diet in Neolithic-Paleometal times was based on hunting terrestrial mammals and freshwater fishing (based on both archaeological and zooarchaeological information). The dearth of human remains makes it impossible to use data on stable isotope analysis. The slow introduction of millet agriculture in the mainland Russian Far East at the end of the Neolithic, 4600 BP, and more actively in the Paleometal Age ( 3000-1500 BP) and the Middle Ages ( 1500-800 BP; in some regions up to $\sim 300 \mathrm{BP}$ ), brought a new source of protein derived from the $\mathrm{C}_{4}$ plants, as has been established using the stable isotope data from human bone collagen. The temporal trend toward a lesser amount of millet as a staple crop (perhaps in favor of $\mathrm{C}_{3}$-type cultigens such as wheat and barley) for the Amur River basin from the Early Iron Age to the Middle Ages is evident (the trend appears as a dashed line with arrow in Figure 2). Also, the ratio of the $\mathrm{C}_{4}$ plant food in the Russian Far East was never as high as in the neighboring northern and northeastern parts of China.

In the insular part of the Russian Far East, namely Sakhalin Island, marine food was a significant part of the human diet in the Early Iron Age and in the Middle Ages ( 2500-400 BP) according to the stable isotope data. Because agriculture based on millet cultivation was never practiced on Sakhalin according to archaeological information (e.g. Kuzmin and Rakov 2011), this conclusion is in agreement with zooarchaeological information for these cultural complexes with abundant shell middens (e.g. Kuzmin et al. 2004; Vasilevsky and Shubina 2006:164-5).

\section{Relevance of Dietary Patterns in Establishing Reliable ${ }^{14} \mathrm{C}$-Based Chronologies in NE Asia}

For the calibration of samples originating from marine organisms, as well as remains of humans who consumed them, knowledge of regional and local reservoir age corrections is essential. Studies on the reservoir effect in the Sea of Japan, the Sea of Okhotsk, and the southern Kurile Islands were conducted by Kuzmin et al. (2001, 2007a). Independent research (e.g. Yoneda et al. 2000, 2007; Kong and Lee 2005; Nakamura et al. 2007) has confirmed our results. Today, the reservoir correction values for the Northeast Asian seas are established with confidence (Figure 1). However, one should be aware that the reservoir age $(R$ and $\Delta R)$ values for the same sea and even part of it are often highly variable (e.g. Kong and Lee 2005; Nakamura et al. 2007), and great care must be taken when calibration of marine and marine-related (e.g. humans with a heavy marine diet) samples is carried out. Thus far, the only data on the past reservoir age that exist for the Russian Far East are from the southern Primorye region, where in the Middle Holocene ( 6000 BP) it was similar to the 
modern values ( $\Delta \mathrm{R} \sim 0$ to $+100 \mathrm{yr}$ ), based on a pair of ${ }^{14} \mathrm{C}$ dates run on marine mollusk shell and hazelnut from the same core and at the same depth (Mikishin et al. 2001).

It has been established that for the Sea of Japan the $\Delta \mathrm{R}$ value is similar to the average marine reservoir offset for the oceans $(\Delta \mathrm{R} \sim 0$; and sometimes up to $+100 \mathrm{yr}$ ) (Kuzmin et al. 2001; Kong and Lee 2005), while the Sea of Okhotsk has much higher $\Delta \mathrm{R}$ values, up to $+580 \mathrm{yr}$ (Kuzmin et al. 2007a; Yoneda et al. 2007, 2010) (Figure 1). In the southern Kuriles, the $\Delta \mathrm{R}$ value $(+350 \mathrm{yr})$ lies somewhere between these numbers, due to the mixture of water of the Oyashio Current with high $\Delta \mathrm{R}$ and water of the Kuroshio Current with low $\Delta \mathrm{R}$ (Kuzmin et al. 2007a; Yoneda et al. 2007; Yoshida et al. 2010; see Figure 1). This information is extremely important for the interpretation of results of ${ }^{14} \mathrm{C}$ dating for human bones from coastal sites of the Russian Far East and neighboring regions, especially Hokkaido Island.

When the calibration of ${ }^{14} \mathrm{C}$ dates run on marine-derived materials and/or remains of organisms that obtained most of the protein from marine sources is conducted, the underestimation of the apparent ${ }^{14} \mathrm{C}$ age could distort the true (i.e. reservoir-corrected) date for several hundred years. This is why it is now required to know and use the regional reservoir correction values, as was done for the Boisman 2 site by Kuzmin et al. (2002), and for the Jomon population of the Kitakogane site on Hokkaido by Yoneda et al. (2002).

\section{CONCLUSIONS}

Based on the available information concerning the diet of the prehistoric and Medieval populations of the Russian Far East, some conclusions can be drawn. The maritime-oriented economy, with a heavy reliance on marine mammals according to the stable isotope data from the Boisman 2 site, was fully developed in the Neolithic on the coast of Primorye region at $\sim 5800-5400$ BP. It can also be suggested that salmon fishing was practiced even earlier, at $7000 \mathrm{BP}$, as the data from the Chertovy Vorota site indicate. The coastal populations of Sakhalin Island also had a marine-based economy since at least Late Neolithic/Paleometal times ( 2500-1600 BP). In the inland regions, the Paleometal population of the Amur River basin at $2500-1800$ BP possibly consumed a large amount of $\mathrm{C}_{4}$ food (cultivated millet), while in the Middle Ages ( 1500-300 BP) the proportion of the $\mathrm{C}_{4}$ type protein source gradually decreased, and $\mathrm{C}_{3}$ food (mainly wheat and barley, and terrestrial animals) dominated in the diet.

As for future studies in the field of paleodiet in the Russian Far East, data on Early Iron Age coastal populations of Primorye need to be obtained in order to understand the role of adaptation to a maritime lifestyle. More work should be done for the Paleometal and Medieval populations of the inland parts in the Amur River basin and Primorye Province, due to the very small amount of current data.

Information about the maritime-oriented diet of the prehistoric and Medieval populations of Primorye and Sakhalin Island should be taken into account when ${ }^{14} \mathrm{C}$ dating of human remains from these regions is undertaken, due to a reservoir correction of $\Delta \mathrm{R}=\sim 0$ to $+100 \mathrm{yr}$ in the Sea of Japan, and up to $+580 \mathrm{yr}$ in the Sea of Okhotsk. Therefore, the study of human diet is now an essential part of geoarchaeological investigations in Northeast Asia.

\section{ACKNOWLEDGMENTS}

This research was supported by the Tomsk State University Program "Academician D I Mendeleev Fund" (2014-5, grant 8.1.22.2015) for Laboratory of Mesozoic and Cenozoic Continental Ecosystems; and by the Russian Foundation for Basic Sciences (RFFI; grant 12-06-00045). I am grateful to Dr Susan G Keates for grammar corrections and to two anonymous reviewers for numerous useful remarks, comments, and suggestions. 


\section{REFERENCES}

Andreeva ZV, editor. 2005. Rossiisky Dalny Vostok $v$ Drevnosti i Srednevekovye: Otkrytiya, Problemy, Gipotezy [The Russian Far East in Prehistory and the Medieval Times: Discoveries, Problems, and Hypotheses]. Vladivostok: Dalnauka Publishers. $696 \mathrm{p}$.

Atahan P, Dodson J, Li X, Zhou X, Chen L, Barry L, Bertuch F. 2014. Temporal trends in millet consumption in northern China. Journal of Archaeological Science 50:171-7.

Barton L, Newsome SD, Chen F-H, Wang H, Guilderson TP, Bettinger RL. 2009. Agricultural origins and the isotopic identity of domestication in northern China. Proceedings of the National Academy of Sciences of the USA 106(14):5523-8.

Choy K, Richards MP. 2010. Isotopic evidence for diet in the Middle Chulmun period: a case study from the Tongsamdong shell midden, Korea. Archaeological and Anthropological Sciences 2(1):1-10.

Choy K, An D, Richards MP. 2012. Stable isotopic analysis of human and faunal remains from the Incipient Chulmun (Neolithic) shell midden site of Ando Island, Korea. Journal of Archaeological Science 39(7):2091-7.

Crawford GW, Takamiya H. 1990. The origins and implications of late prehistoric plant husbandry in northern Japan. Antiquity 64(245):889-911.

D’Andrea AC, Crawford GW, Yoshizaki M, Kudo T. 1995. Late Jomon cultigens in northeastern Japan. Antiquity 69(262):146-52.

DeNiro M. 1985. Postmortem preservation and alteration of in vivo bone collagen isotope ratios in relation to palaeodietary reconstruction. Nature 317(6040):806-9.

Fitzhugh WW, Dubreuil CO, editors. 1999. Ainu: Spirit of a Northern People. Washington, DC: Smithsonian Institution Press. 415 p.

Hou L, Hu Y, Zhao X, Li S, Wie D, Hou Y, Hu B, Lv P, Li T, Song G, Wang C. 2013. Human subsistence strategy at Liuzhuang site, Henan, China during the proto-Shang culture ( 2000-1600 BC) by stable isotopic analysis. Journal of Archaeological Science 40(5):2344-51.

Kong GS, Lee CW. 2005. Marine reservoir corrections $(\Delta \mathrm{R})$ for southern coastal waters of Korea. The Sea, Journal of Korean Society for Oceanography 10(2):124-8. In Korean with English abstract.

Kusaka S, Yodo F, Yumoto T, Nakatsukasa M. 2010. Carbon and nitrogen stable isotope analysis on the diet of Jomon populations from two coastal regions of Japan. Journal of Archaeological Science 37(8):1968-77.

Kuzmin YV. 1997. Vertebrate animal remains from prehistoric and Medieval settlements in Primorye (Russian Far East). International Journal of Osteoarchaeology 7(2):172-80.

Kuzmin YV. 2006. Palaeoeconomy of the Russian Far East (Stone Age complexes). In: Nelson SM, Dere- vianko AP, Kuzmin YV, Bland RL, editors. Archaeology of the Russian Far East: Essays in Stone Age Prehistory. Oxford: Archaeopress. p 167-73.

Kuzmin YV. 2009. Prehistoric maritime adaptation on the Pacific coast of Russia: results and problems of geoarchaeological research. North Pacific Prehistory 3:115-39.

Kuzmin YV. 2012. Radiocarbon chronology for prehistoric complexes of the Russian Far East: 15 years later. Radiocarbon 54(3):727-36.

Kuzmin YV. 2013. The beginnings of prehistoric agriculture in the Russian Far East: current evidence and concepts. Documenta Praehistorica 40:1-12.

Kuzmin YV, Rakov VA. 2011. Environment and prehistoric humans on the Russian Far East and neighbouring East Asia: main patterns of interaction. Quaternary International 237(1-2):103-8.

Kuzmin YV, Burr GS, Jull AJT. 2001. Radiocarbon reservoir correction ages in the Peter the Great Gulf, Sea of Japan, and eastern coast of the Kunashir, southern Kuriles (northwestern Pacific). Radiocarbon 43(2A):477-81.

Kuzmin YV, Richards MP, Yoneda M. 2002. Palaeodietary patterning and radiocarbon dating of Neolithic populations in the Primorye Province, Russian Far East. Ancient Biomolecules 7(4):48-53.

Kuzmin YV, Richards M, Bolotin DP. 2003. Dieta naseleniya Zeisko-Bureinskoi ravniny (Priamurye) v rannem zheleznom veke i srednevekovye (po dannym izotopnogo sostava ugleroda i azota v kollagene kostei) [Diet of the population of Zeya-Bureya Plain (Amur River basin) in the Early Iron Age and the Middle Ages (based on isotope composition of carbon and nitrogen in bone collagen)]. In: Matveeva NP, editor. Ekologiya Drevnikh i Sovremennykh Obshchestv. Vypusk 2. Tuymen: Izdatelstvo IPOS SO RAN. p 132-3. In Russian.

Kuzmin YV, Vasilevski AA, Gorbunov SV, Burr GS, Jull AJT, Orlova LA, Shubina OA. 2004. Chronology of prehistoric cultural complexes of Sakhalin Island (Russian Far East). Radiocarbon 46(1):353-62.

Kuzmin YV, Burr GS, Gorbunov SV, Rakov VA, Razjigaeva NG. 2007a. A tale of two seas: reservoir age correction values $(R, \Delta R)$ for the Sakhalin Island (Sea of Japan and Okhotsk Sea). Nuclear Instruments and Methods in Physics Research B 259(1):460-2.

Kuzmin YV, Gorbunov SV, Richards MP, Vasilevski AA. 2007b. Diet of prehistoric and ethnographic coastal human populations of the Sakhalin Island (Russian Far East). In: Kharinsky AV, editor. The Ethnohistory and Archaeology of Northern Eurasia: Theory, Methods and Practice. Irkutsk: Irkutsk State Technical University Press. p 332-6.

Kuzmin YV, Keally CT, Jull AJT, Burr GS, Klyuev NA. 2012. The earliest surviving textiles in East Asia from Chertovy Vorota Cave, Primorye Province, Russian Far East. Antiquity 86(332):325-37. 
Lanehart RE, Tykot RH, Underhill AP, Luan F, Yu H, Fang H, Fengshu C, Feinman G, Nicholas L. 2011. Dietary adaptation during the Longshan period in China: stable isotope analyses at Liangchengzhen (southeastern Shandong). Journal of Archaeological Science 38(9):2171-81.

Liu X, Jones MK, Zhao Z, Liu G, O'Connell TC. 2012. The earliest evidence of millet as a staple food: new light on Neolithic foodways in North China. American Journal of Physical Anthropology 149(2):28390

Ma MM, Dong GH, Lightfoot E, Wang H, Liu XY, Jia X, Zhang KR, Chen FH. 2014. Stable isotope analysis of human and faunal remains in the Western Loess Plateau, approximately 2000 cal BC. Archaeometry 56(Supplement):237-55.

Mikishin YA, Popov AN, Petrenko TI, Rakov VA, Orlova LA, Jull AJT. 2001. Development of coastal environments on Boisman Bay (Peter the Great Bay, southern Primorye) during the Holocene. In: Kasyanov VL, editor. Reports of the International Workshop on the Global Change Studies in the Far East. Vladivostok: Dalnauka Publishers. p 58-71.

Minagawa M, Akazawa T. 1992. Dietary patterns of Japanese Jomon hunters-gatherers: stable carbon and nitrogen isotope analyses of human bones. In: Aikens CM, Rhee SN, editors. Pacific Northeast Asia in Prehistory: Hunters-Fishers-Gatherers, Farmers, and Sociopolitical Elites. Pullman: Washington State University Press. p 59-67.

Naito YI, Honch NV, Chikaraishi Y, Ohkouchi N, Yoneda M. 2010. Quantitative evaluation of marine protein contribution in ancient diets based on nitrogen isotope ratios of individual amino acids in bone collagen: an investigation at the Kitakogane Jomon site. American Journal of Physical Anthropology 143(1):31-40.

Nakamura T, Nishida I, Takada H, Okuno M, Minami M, Oda H. 2007. Marine reservoir effect deduced from ${ }^{14} \mathrm{C}$ dates on marine shells and terrestrial remains at archeological sites in Japan. Nuclear Instruments and Methods in Physics Research B 259(1):453-9.

Pechenkina EA, Ambrose SH, Ma X, Benfler RA Jr. 2005. Reconstructing northern Chinese Neolithic subsistence practices by isotopic analysis. Journal of Archaeological Science 32(8):1176-89.

Popov AN, Yesner DR. 2006. Early maritime adaptation on the southern coast of the Far East of Russia in ancient times. In: Peterson DL, Popova LM, Smith AT, editors. Beyond the Steppe and the Sown. Leiden: Brill. p 469-76.

Popov AN, Tabarev AV, Mikishin YA. 2014. Neolithization and ancient landscapes in southern Primorye, Russian Far East. Journal of World Prehistory 27(3-4):247-61.

Richards MP, Hedges REM. 1999. Stable isotope evidence for similarities in the types of marine foods used by late Mesolithic humans at sites along the Atlantic coast of Europe. Journal of Archaeological Science 26(6):717-22.
Roksandic Z, Minagawa M, Akazawa T. 1988. Comparative analysis of dietary habits between Jomon and Ainu hunter-gatherers from stable carbon isotopes of human bone. Journal of Anthropological Society of Nippon 96(4):391-404.

Tabarev AV. 2014. The later prehistory of the Russian Far East. In: Renfrew C, Bahn P, editors. The Cambridge World Prehistory. Volume 2: East Asia and the Americas. New York: Cambridge University Press. p 852-69.

Tsutaya T, Sawada J, Dodo Y, Mukai H, Yoneda M. 2013. Isotopic evidence of dietary variability in subadults at the Usu-moshiri site of the Epi-Jomon culture, Japan. Journal of Archaeological Science 40(11):3914-25.

Tsutaya T, Naito YI, Ishida H, Yoneda M. 2014. Carbon and nitrogen isotope analyses of human and dog diet in the Okhotsk culture: perspectives from the Moyoro site, Japan. Anthropological Science 122(2):89-99.

Vasilevsky AA, Shubina OA. 2006. Neolithic of the Sakhalin and southern Kurile Islands. In: Nelson SM, Derevianko AP, Kuzmin YV, Bland RL, editors. Archaeology of the Russian Far East: Essays in Stone Age Prehistory. Oxford: Archaeopress. p 151-66.

Yoneda M, Kitagawa H, van der Plicht J, Uchida M, Tanaka A, Uehiro T, Shibata Y, Morita M, Ohno T. 2000. Pre-bomb reservoir ages in the western North Pacific: preliminary result on Kyoto University collection. Nuclear Instruments and Methods in Physics Research B 172(1-4):377-81.

Yoneda M, Tanaka A, Shibata Y, Morita M. 2002. Radiocarbon marine reservoir effect in human remains from the Kitakogane site, Hokkaido, Japan. Journal of Archaeological Science 29(5):529-36.

Yoneda M, Suzuki R, Shibata Y, Morita M, Sukegawa T, Shigehara N, Akazawa T. 2004. Isotopic evidence of inland-water fishing by a Jomon population excavated from the Boji site, Nagano, Japan. Journal of Archaeological Science 31(1):97-107.

Yoneda M, Uno H, Shibata Y, Suzuki R, Kumamoto Y, Yoshida K, Sasaki T, Suzuki A, Kawahata H. 2007. Radiocarbon marine reservoir ages in the western Pacific estimated by pre-bomb molluskan shells. Nuclear Instruments and Methods in Physics Research B 259(1):432-7.

Yoshida K, Hara T, Kunikita D, Miyazaki Y, Sasaki T, Yoneda M, Matsuzaki H. 2010. Pre-bomb marine reservoir ages in the western Pacific. Radiocarbon 52(3):1197-206.

Zhang Q, Feng E, Zhu H. 2009. Paleodiet studies using stable carbon and nitrogen isotopes from human bone: an example from the Troitskiy cemetery of Mohe, far-eastern Russia. Acta Anthropologica Sinica 28(3):300-5. In Chinese with English abstract.

Zhushchikhovskaya IS. 2006. Neolithic of the Primorye. In: Nelson SM, Derevianko AP, Kuzmin YV, Bland RL, editors. Archaeology of the Russian Far East: Essays in Stone Age Prehistory. Oxford: Archaeopress. p 101-22. 